\title{
Malaria Prophylaxis and Vaccinations Among Turkish International Travelers: National Data, 2011-2016
}

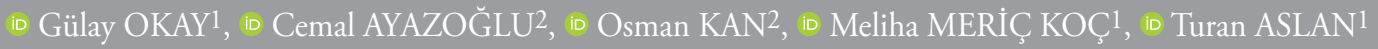

1Bezmialem Vakıf University Faculty of Medicine, Department of Infectious Diseases and Clinical Microbiology, İstanbul, Turkey

${ }^{2}$ Ministry of Health, Turkey Directorate General of Health for Borders and Coastal Areas, İstanbul, Turkey

\begin{abstract}
Objective: The number of international travelers is increasing steadily. As a result, there is also an increase in travel-related infections. There is not enough data on travel vaccinations and prophylaxis in Turkey. The aim of this study is to create awareness and to guide national politics by presenting national data of Turkey.

Methods: Travelers who took travel health services (THS) at travel health centers (THC) during 2011-2016 were included in the study. The data in the THC's record system were examined for age, sex, purpose of travel, duration of stay, country of destination, learning source of THS, vaccinations and malaria prophylaxis.

Results: During the study period, 162,023 people took THS. There was a 57\% increase in the number of travelers who took THS in 2016 compared to 2011 . There was no significant increase in the incidence of THS in Turkish travelers going abroad $(0.33 \%$ and $0.43 \%$, respectively in 2011 and 2016) ( $\mathrm{rs}=0.36 \mathrm{p}=0.47)$. The most common reason for traveling was business trips $(79 \%)$, the most visited region was Africa $(65.7 \%)$. The percentages of yellow fever vaccine, typhoid vaccine and malaria prophylaxis were $86.7 \%, 28.3 \%$, and $44.7 \%$, respectively.

Conclusion: The main reason for travel was business and the most frequent destination was Africa. The number of travelers who took THS in travelers going abroad was very low in our country. It was concluded that awareness of travel-related health risks and preventive measures in the community should be increased.
\end{abstract}

Keywords: Travel health, malaria prophylaxis, travel vaccination

\section{Introduction}

In the world, millions of people travel every day for various reasons. Despite the threats emerging due to the outbreaks such as influenza and severe acute respiratory syndrome, there has been an on-going growth in tourism during the last six decades (1). Destinations around the world welcomed about one billion international tourists in 2016 (2). Travelers are exposed to a variety of health risks in unfamiliar areas and are involved in the spread of global infections (3). Health risks that travelers may face are determined by the level of development of the destination, season, duration, purpose of travel (trip, to work in rural areas, visit friends etc.), hygiene standards of accommodation, activities (camping, diving, hunting), age and health condition of travelers $(4,5)$. Malaria, dengue, enteric fever, chikungunya, non-specific viral syndromes, rickettsioses are the most common infectious diseases among international travelers (6) Most of travel-related health risks can be prevented or minimized by health measures to be taken before, during and after travel. Travel health services (THS) are important for travel-related diseases, because they provide vaccines, pre-travel advice and other preventive measures such as information on preventing insect bites, food and water safety precautions (7). 
In Turkey, Ministry of Health, Travel Health Centers (THC) have provided THS for many years. There is not enough data in the literature about travel vaccinations and prophylaxis in Turkey. The aim of this study is to discuss the topic with regard to possible improvements, to create awareness and to guide national politics by presenting national data of Turkey.

\section{Methods}

In Turkey, THSs (pre-travel advice, vaccinations and malaria prophylaxis) are provided by THC run by the Ministry of Health, Turkey Directorate General of Health for Borders and Coastal Areas. THCs are also authorized centers for issuing an "International Vaccination and Prophylaxis Certificate" in Turkey. Pre-travel advice, vaccinations and malaria prophylaxis are provided in line with the national, US Centers for Disease Control and Prevention and World Health Organization guidelines. Travel health call center connected to the General Directorate also make counseling and travelers directed to THCs, if required.

All international travelers who attended THCs during 1 January 2011-31 December 2016 were included in this study. The following data about international travelers were collected retrospectively from the Directory's THCs record system: Age, sex, purpose of travel, duration of stay, and country of destination, recommendation of vaccines and malaria prophylaxis and learning sources of THCs. The age of travelers categorized into 3 groups ( $<15$ years, $15-45$ years, $>45$ years). Time of travel was defined as less than 10 days and more than 10 days. Purposes of travel were divided into four groups (Business, holiday, residency and others). All variables were categorical and descriptive statistics were defined as percentages and numbers. Data processing was performed in Microsoft Office Excel 2007 and SPSS (version 16.0). Pearson correlation test was used for correlation of incidence of THS by years.

The study was approved by the Ethics Committee of Bezmialem Foundation University (decision date/number: 16-01-2018 / $2 / 10$ ). Written consent was not obtained from patients because the research was done retrospectively.

\section{Results}

During the study period, THS were provided for 162,023 people. The number of travelers who took THS was shown in Figure 1. The number of total international Turkish travelers increased by $57 \%$ and $19.4 \%$, respectively in 2016 compared to 2011 (8). The incidence of THS for total Turkish travelers was found to be $0.33 \%$ and $0.43 \%$, respectively in 2011 to 2016 . There was not a significant correlation between the incidence of THS and years ( $\mathrm{rs}=0.36 \mathrm{p}=0.47)$.

Demographic and travel characteristics of the travelers who took THS are shown in Table 1. Of all the travelers; $82.8 \%$ were male, $77.8 \%$ were between $15-45$ years old, and $1.6 \%$ were under 15 years old. Of all the travelers; $91(0.06 \%)$ were pregnant, $92(0.06 \%)$ were nursing mothers, $16.9 \%$ were seafarers and
$8.9 \%$ were flight staff travelling internationally due to their occupational status.

In most of these travels, the travel purpose was business (79\%). The second most common travel purpose was holiday (11.6\%). When the duration of travel was evaluated, most of trips lasted more than 10 days $(61 \%)$. When we assessed the travelers according to the regions of destination, African countries were at the top (65.7\%). Distribution of the first six most frequently visited regions are shown in Table 1.

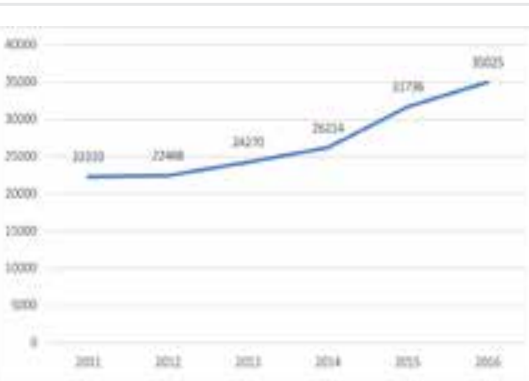

Figure 1. The number of travelers who took travel health services by years

Table 1. Demographic and travel characteristics of the travelers (2011-2016)

\section{Features}

\section{Sex}

Male

\section{Age}

$<15$

$15-45$

$>45$

Pregnant

Nursing

Seafarers

Flight staff

\section{Destination}

East Africa

West Africa

Central Africa

South and Southeast Asia

South Africa

South America

Purpose of travel

Busines

Holiday

Other

Duration of stay (day)

$<10$

$>10$

Chronic diseases

Yes n (\%)

\section{$134,113(82.8)$}

2,598 (1.6)

126,084 (77.8)

33,341 (20.6)

$91(0.06)$

$92(0.06)$

27,436 (16.9)

$14,557(8.9)$

$39,158(24)$

39,354 (24)

$19,083(12)$

$8,565(5.3)$

$7,534(4.6)$

4,648 (2.9)

$128,117(79)$

18,881 (11.6)

$15,025(9.4)$

62,729 (39)

99,294 (61)

$3,924(2.4)$ 
Rates of vaccinations and malaria prophylaxis given are shown in Table 2. Of travelers, $86.7 \%$ were vaccinated with yellow fever vaccine. Typhoid vaccine and malaria prophylaxis rates were $28.3 \%$ and $44.7 \%$, respectively during study period.

The distribution of the drugs for malaria prophylaxis is shown in Table 3. Doxycycline was most frequently (41.2\%) used drug for malaria prophylaxis during study period. Atovaquone-proguanil and Mefloquine were used in $35.4 \%$ and $23.4 \%$ of the travelers, respectively.

Resources from which THS were learned are shown in Table 4. Most of the travelers were directed to the THCs by their companies (31.4\%). Of travelers, $13.4 \%$ came on the advice of their friends and $6.9 \%$ of them learned the THCs through the internet.

\section{Discussion}

The number of international travelers in Turkey have been increasing day by day like the rest of the world. Traveling from Turkey to different regions for various reasons such as business, holiday, congress, reached up to eight million in 2016 (8). Health risks during international travel are determined by many factors like destination, region, age and health status of the traveler, duration and type of the travel and the planned activities (4). According to the data of the GeoSentinel Surveillance Network, the region where international travelers encounter diseases most frequently is Sub-Saharan Africa (23\%) and the

Table 2. Number of people to whom vaccine and malaria prophylaxis were given (2011-2016)

\begin{tabular}{|l|l|}
\hline Vaccine and chemoprophylaxis & $\mathrm{n}(\%)$ \\
\hline Yellow fever & $140,423(86.7)$ \\
\hline Typhoid & $45,954(28.3)$ \\
\hline Malaria prophylaxis* & $72,481(44.7)$ \\
\hline *Malaria prophylaxis: Mefloquine, atovaquone-proguanil, doxycycline \\
\hline
\end{tabular}

Table 3. Distribution of malaria prophylaxis medications (2011-2016)

\begin{tabular}{|l|l|}
\hline Malaria prophylaxis medications & $\mathrm{n}(\%)$ \\
\hline Doxycycline & $29,883(41.2)$ \\
\hline Atovaquone-proguanil & $25,701(35.4)$ \\
\hline Mefloquine & $16,897(23.4)$ \\
\hline Total & $72,481(100)$ \\
\hline
\end{tabular}

Table 4. Resources from which travel health services were learned (2011-2016)

\begin{tabular}{ll} 
Sources & $\mathrm{n}(\%)$ \\
\hline Company & $50.709(31.4)$ \\
Friends & $21.335(13.3)$ \\
Internet & $11.222(6.9)$ \\
Travel health call center & $3.463(2.2)$ \\
Other & $16.616(10)$ \\
No data & $58.678(36.2)$ \\
\hline
\end{tabular}

most frequent diseases are acute diarrhea (22\%), inflammatory/ systemic diseases (14\%) and dermatological diseases (12\%) (9). People travelling to tropical and subtropical countries may face different infectious diseases and may cause transmission of these diseases to the countries where they are not endemic $(10,11)$. Due to its extensive geographical distribution and potential fatal results, malaria is one of the most important travel-related diseases. Malaria is diagnosed in 29\% of returnees with fever and seen mostly in passengers returning from Africa $(12,13)$. Most of these cases are related to Sub-Saharan Africa and in $60 \%$ of them, the agent is Plasmodium falciparum (14). Vaccinepreventable diseases also take an important place among travelrelated infections (9). Vaccine-preventable diseases (enteric fever, acute viral hepatitis and influenza most frequently) are seen in $1.5 \%$ of returnees $(9)$.

THS should be received before travel in order to take necessary advice for these health risks, to be vaccinated and to begin to use protective medications (15). Ideally, the most convenient time to do this is 4-6 weeks before travel, but it is important to benefit from this service even if it is the last week. In pre-travel consultation, all factors should be assessed and personal advice should be given. Vaccination is the most important component of this consultation (4).

In Turkey, Ministry of Health, Turkey Directorate General of Health for Borders and Coastal Areas is giving THS by THCs, travel health call center and official travel health website (www. seyahatsagligi.gov.tr). Travel health website give information about infectious diseases seen in countries, required and recommended vaccinations, malaria prophylaxis, and other travel related health risks. When the number of people travelling internationally (eight million) every year in Turkey is considered, it is seen that the number of people for whom we provide THS is quite low. Although the number of travelers receiving THS has increased over the years $(57 \%)$, there was not a significant correlation in the incidence of THSs by years ( $\mathrm{rs}=0.36 \mathrm{p}=0.47$ ). In the studies performed before, it was also reported that most of the travelers did not receive consultation before travel, and most of those who receive consultation, did this through friends, travel agencies, pharmacies and internet and they rarely visit doctors $(15-17)$. In a study on travelers going to Africa, it was shown that only half of the passengers received pre-travel consultancy (18).

Evaluation of our study group for demographic features indicated that similar to other studies, most of the travelers were male and young/middle-aged (16-18). While in our study, coexisting diseases were detected in $2.4 \%$ of the travelers, in the reports of Global TravEpiNet, coexisting health problems were notified in 53\% of travelers (19). When we assessed the travelers for travel purposes, we concluded that in comparison to similar studies, the travel rates for business purposes were high whereas for holiday purposes were low $(18,20,21)$. Global TravEpiNet has also declared that according to the collected data, most frequently reported travel purpose is holiday (49\%) and the others are business (15\%), service work (15\%) and visiting relatives (11\%) (19). 
In our study, yellow fever vaccination rate $(86.7 \%)$ was higher in comparison to other studies $(5,18,20,22)$. This outcome was thought to be the result of THCs' being the only authorized ones in the country for yellow fever vaccination and yellow fever vaccine is an obligatory vaccine. When we consider that most of travelers went to typhoid endemic regions for business purposes and for long durations, typhoid vaccination rate (28.3\%) was lower than expected $(16,23)$. In Turkey, for other routine vaccinations, travelers are directed to family physicians. It has been evaluated that providing these vaccinations in THCs is important for increasing and pursuing the other vaccination rates.

The most frequent travel destinations of Turkish travelers were African countries (61.4\%). It is thought that the most important reason for such a high rates for travelling to African countries is the increase in business relations between our country and African countries in recent years. Another reason is that the African countries are endemic for yellow fewer and vaccination is required for entering these countries. On the website of Global TravEpiNet, it has been reported that more than $80 \%$ of travelers visit the countries with less resources and that Africa is the most frequently visited region (20). In many other studies, Africa has also been reported as the most visited region (22). It has been understood that travelers who contact us are mostly directed by companies or are recommended by their friends and that their awareness about travel health is low.

\section{Conclusion}

The number of travelers going abroad who take THS are very low in our country. We conclude that, we should reach out more people in order to access the purpose of THS. The awareness of travel-related health risks and preventive measures in the community should be increased. For this purpose, it can be planned to inform people who plan to travel abroad about THS through travel agencies and aviation companies and to raise awareness by preparing informative publications in the national press.

\section{Ethics}

Ethics Committee Approval: The study was approved by the Ethics Committee of Bezmialem Foundation University (decision date/number: 16-01-2018 / 2/10).

Informed Consent: Written consent was not obtained from patients because the research was done retrospectively.

Peer-review: Externally peer-reviewed.

\section{Authorship Contributions}

Concept: G.O., C.A., O.K., M.M.K., T.A., Design: G.O., C.A., O.K., M.M.K., T.A., Data Collection or Processing: G.O., C.A., O.K., Analysis or Interpretation: G.O., C.A., Literature Search: G.O., C.A., Writing: G.O.

Conflict of Interest: No conflict of interest was declared by the authors.
Financial Disclosure: The authors declared that this study received no financial support.

\section{References}

1. Keystone JS, Kozarsky PE, Freedman DO, Connor BA, Nothdurft HD. eds. Travel Medicine, 3rd Edition. Saunders, Edinburgh: Elsevier 2013.

2. Close to one billion international tourists in the first nine months of 2016 07-Nov-2016 [Available from: http://media.unwto.org/pressrelease/2016-11-07/close-one-billion-international-tourists-firstnine-months-2016.

3. Gautret P, Schlagenhauf P, Gaudart J, Castelli F, Brouqui P, von Sonnenburg F, et al. Multicenter EuroTravNet/GeoSentinel study of travel-related infectious diseases in Europe. Emerging Infect Dis 2009;15:1783-90.

4. Chen L. The Pre-travel Consultation. Brunette G, editor. New York: Oxford University Press; 2014.

5. LaRocque RC, Rao SR, Lee J, Ansdell V, Yates JA, Schwartz BS, et al. Global TravEpiNet: a national consortium of clinics providing care to international travelers--analysis of demographic characteristics, travel destinations, and pretravel healthcare of high-risk US international travelers, 2009-2011. Clinical Infectious Dis 2012;54:455-62.

6. Sotir MJ LR. Travel epidemiology. GW B, editor. New York: Oxford University Press; 2016. 11-4p.

7. Wieten RW, van der Schalie M, Visser BJ, Grobusch MP, van Vugt M. Risk factors and pre-travel healthcare of international travellers attending a Dutch travel clinic: a cross-sectional analysis. Travel Med Infect Dis 2014;12:511-24.

8. Our citizens traveling abroad and tourism expenses. Number of citizens going abroad by years [Available from: http://www.tuik. gov.tr/jsp/duyuru/upload/yayinrapor/Vatandas_Giris_Anketi_ Raporu_2013.pdf.

9. Boggild AK, Castelli F, Gautret P, Torresi J, von Sonnenburg F, Barnett $\mathrm{ED}$, et al. Vaccine preventable diseases in returned international travelers: results from the GeoSentinel Surveillance Network. Vaccine 2010;28:7389-95.

10. Khan K, Arino J, Hu W, Raposo P, Sears J, Calderon F, et al. Spread of a novel influenza $A(\mathrm{H} 1 \mathrm{~N} 1)$ virus via global airline transportation. N Engl J Med 2009;361:212-4.

11. Freedman DO, Weld LH, Kozarsky PE, Fisk T, Robins R, von Sonnenburg F, et al. Spectrum of disease and relation to place of exposure among ill returned travelers. N Eng J Med 2006;354:11930.

12. Harvey K, Esposito DH, Han P, Kozarsky P, Freedman DO, Plier DA, et al. Surveillance for travel-related disease--GeoSentinel Surveillance System, United States, 1997-2011. MMWR Surveill Summ 2013;62:1-23.

13. Leder K, Torresi J, Libman MD, Cramer JP, Castelli F, Schlagenhauf P, et al. GeoSentinel surveillance of illness in returned travelers, 20072011. Ann Intern Med 2013;158:456-68.

14. Leder K, Black J, O’Brien D, Greenwood Z, Kain KC, Schwartz E, et al. Malaria in travelers: a review of the GeoSentinel surveillance network. Clinical infectious diseases : an official publication of the Infectious Diseases Society of America. 2004;39(8):1104-12. 
15. Gherardin T. The pre-travel consultation-an overview. Australian family physician 2007;36:300-3.

16. Van Herck K, Zuckerman J, Castelli F, Van Damme P, Walker E, Steffen R. Travelers' knowledge, attitudes, and practices on prevention of infectious diseases: results from a pilot study. J Travel Med 2003;10:75-8.

17. Wilder-Smith A, Khairullah NS, Song JH, Chen CY, Torresi J. Travel health knowledge, attitudes and practices among Australasian travelers. J Travel Med 2004;11(:9-15.

18. Pavli A, Spilioti A, Smeti P, Patrinos S, Maltezou HC. Vaccination and Malaria Prevention among International Travelers Departing from Athens International Airport to African Destinations. J Trop Med 2014;2014:563-30.

19. Regina C L, David O. Freedman, Mark J. Sotir. Travel Medicine Data Collection: Geosentinel and Global Travepinet. Brunette GW, editor. New York: Oxford University press;2014.
20. LaRocque RC, Rao SR, Tsibris A, Lawton T, Barry MA, Marano N, et al. Pre-travel health advice-seeking behavior among US international travelers departing from Boston Logan International Airport. J Travel Med 2010;17:387-91.

21. Heywood AE, Watkins RE, Iamsirithaworn S, Nilvarangkul K, MacIntyre CR. A cross-sectional study of pre-travel health-seeking practices among travelers departing Sydney and Bangkok airports. BMC public health 2012;12:321.

22. Heudorf U, Tiarks-Jungk P, Stark S. [Travel medicine and vaccination as a task of infection prevention--data of the special consultation hours of the public health department Frankfurt on the Main, Germany, 2002-2004]. Gesundheitswesen 2006;68:316-22.

23. Lopez-Velez R, Bayas JM. Spanish travelers to high-risk areas in the tropics: airport survey of travel health knowledge, attitudes, and practices in vaccination and malaria prevention. J Travel Med 2007; 14:297-305. 